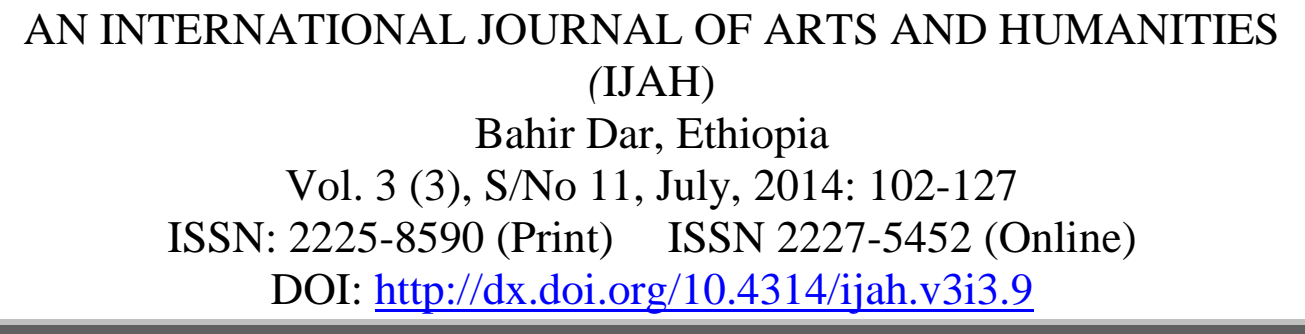

\title{
NIGERIA'S COBWEB OF CORRUPTION AND THE PATH TO UNDERDEVELOPMENT
}

\author{
ALLIYU, Nurudeen, Ph.D., \\ Department of Sociology \\ Olabisi Onabanjo University, Ago Iwoye, Nigeria \\ E-mail: octomay07@yahoo.com \\ $+2348035550187$ \\ KALEJAIYE, Peter O. \\ Department of Sociology \\ Olabisi Onabanjo University, Ago Iwoye, Nigeria \\ E-mail: petkal2000@yahoo.com \\ Phone: +2348052334309 \\ $\&$ \\ OGUNOLA, Abiodun A. \\ Department of Psychology \\ Olabisi Onabanjo University, Ago Iwoye, Nigeria \\ E-mail: psychabiodun@gmail.com \\ Phone: +2347032329181
}




\begin{abstract}
Corruption in Nigeria has grown slowly from the time of pre-independence and it has surely taken over Nigerians' public and private spaces in the last five decades with compelling evidences to show first among the legislative, the executives and recently the judicial arms of government as well as the unexpected quarters in the private sectors such as the Stock Exchange. This paper highlights several factors and institutions in Nigerian society that have sustained and entrenched corrupt practices by government officials and high profile private sectors participants. The institutions identified here are regarded as eaters of corruption proceeds around which a cobweb of corruption has been weaved by the corrupt public/private individuals to create a network under the control of the grandfather- spider of corruption (The federal government); the father-spiders (the state government) and the children-spider (the local governments spread across the Nigerian society). The paper concludes that corruption is a national thing in Nigeria and that the over centralization and the control of means of survival by the grandfather spider has weakened almost all major institutions in the Nigerian society; created a Master-Servant, Lordship and Serfs relationship, which if not re-structured will continue to sustain corruption and perpetuate further development of underdevelopment of the Nigeria Scale and Society. Therefore, Nigerians should shun corruption and see it as a major problem to development in Nigeria.
\end{abstract}

Key Words: Corruption, underdevelopment, cobweb, leaders, masses, Nigeria

\title{
Introduction
}

For many years, Nigeria has had a reputation for being among the most corrupt countries in the world. Transparency International reports from 2002-2009 indicated that the corruption perception index which relates to the perception of the degree of corruption as seen by business people and country analysts, rated Nigeria as the second most corrupt country in the world in 2002, 2003 and 2004 with an index of just 1.6, 1.4 and 1.6 respectively. In 2009, Nigerian corruption perception index improved to 2.5 and ranked 113 (in order of least to the most corrupt) out of 180 countries surveyed in the world. Recently, Nigeria was ranked 33rd most corrupt country in the world, according to the latest report by German-based Transparency International, TI. In the group's Corruption Perceptions Index 2013, Nigeria ranked 144th, out of 177 nations in the world, scoring 25 points out of a possible 100 points. With a score of 63 points, Botswana, the southern African nation, is rated the cleanest African country. It is the 30th in the world. Ghana with 46 points emerged $63 \mathrm{rd}$ in the world. The most corrupt nation in the world is war-torn Somalia, scoring eight points alongside North Korea and crisis-ridden Afghanistan, also with eight points. While 
the most corrupt section is dominated by Africans countries, Europe and a handful of Asian countries are the cleanest. According to the report, Denmark and New Zealand are the cleanest countries in the world, sharing the first spot in the index, with scores of 91.Finland, Sweden, Norway, Singapore, Switzerland, Netherlands, Australia and Canada emerged in the top 10 of least corrupt nations in the world. Nigeria's corruption performance this year was worse than last year's, when it scored 27 points. According to Egwaikhide (2009), the phenomena called corruption manifests in Nigeria in various forms such as political corruption, electoral corruption, bureaucratic corruption, bribery, embezzlement, extortion, fraud, nepotism, favouritism, examination malpractice, impersonation, sex for favour, and other unwholly activities that are a clog on the wheels of economic growth and development.

The Global Competitiveness Index report's competitiveness ranking (GCI), developed for the world economic Forum, rated Nigeria poor in terms of development. The ranking was based on 12 pillars of competitiveness landscape in countries around the world at all stages of development. The pillars are institutions, infrastructure, macroeconomic environment, health and primary education, higher education and training, good market efficiency, labour market efficiency, financial market development, technology readiness, market size, business sophistication, and innovation (World Economic Forum, 2011). According to the GCI report ( 2011), Nigeria ranked the least among six (6) major economies in Africa, with a Global Competitiveness Index of just 3.38 behind Uganda (3.51), Ghana (3.56), Botswana (3.69), Egypt (4.00) and South Africa (4.32) due to corruption. Although scholars have noted that corruption is not a modern day development in Nigeria, it has, however, been established that it is a product of several social, political, economic and historical circumstances (Akanbi, 2004). Corruption is seen as a symptom of numerous difficulties in Nigeria. It usually involves more than one party. It takes the form of an organized crime. It is found in the awards of contracts, promotion of staff, dispensation of justice, and misuse of public offices, positions, and privileges, embezzlements of public funds and admission into higher institutions.

With this in mind, this paper tends to examine the cobweb of Nigeria's corruption and corruption as path to underdevelopment in Nigeria. This broad objective can be reinterpreted as a discussion: on the meaning of corruption; the dimensions of corruption in Nigeria; the meaning of underdevelopment in relation to corruption and their theoretical frame of analysis, and consequences of corruption as path to underdevelopment in Nigeria. Although, the paper did not capture all the sectors or institutions that have been characterized with corruption in Nigeria, yet attention was focused on some key sectors or institutions of Nigerian society. 


\section{Defining Corruption: A Conceptual Excursion}

The word corruption is originally from the Latin verb 'rumpere' which means to break. Following from the above, corruption means the breaking of certain code of conduct for the personal benefit of the perpetrator. For example, Sen, defines it as "the violation of established rules for personal gain and profit", cited in (Aluko 2009:2). Osoba defines it as "an anti-social behaviour conferring improper benefits contrary to legal and moral norms, and which undermines the capacity of authorities to improve the living conditions of the people", cited in (Aluko, 2009:3). In the view of Dike (2003), it is a behaviour which deviates from the formal duties of the public roles because of private gain or expectation of private gain. In essence, corruption entails an abuse of official position for private gain.

An application of the above definitions of corruption in Nigeria clearly reveals that corruption has become an acceptable way of life and has found its way into every sphere of national existence. This is because the indicators of corruption like embezzlement, bribery, misappropriation, conversion of public funds to personal purse, manipulation of procurement processes, falsification of official financial records, award of contracts by public office holders to cronies and personally held companies and rigging of elections are all easily observable in virtually all public offices and public affairs in Nigeria.

The difficulty of defining corruption is first a function of it being a secret and clandestine activity and secondly because it has many manifestations, dimensions and forms that makes it a very difficult concept to define and or describe. Azuka (2012) paint a graphic illustration of the brand of corruption in the public sector in Nigeria as presented in appendix 1 of this paper.

Perhaps the above analogy and may be other complexities made Johnston argue that studying corruption is a tricky business and that partial study will only limit a comprehensive understanding of the phenomenon. According to him; definitions are controversial, and solid evidence is often elusive. Descriptive accounts may be clouded by self-serving equivocations. Equally subtle is the question of the significance of a corrupt act - not only its consequences, but also its meaning as perceived by citizens and officials alike (Ogundiya, 2009:282). Be that as it may, Tanzi has argued that while it may not be easy to define corruption, the crises associated with corruption are not difficult to recognize (Tanzi, 1998). The World Bank defines corruption as:

the abuse of public office for private office private gains. Public office is abused for private gain when an official accepts, solicits, extorts a bribe. It is also abused when private agent actively bribes to 
circumvent public polices and processes for competitive advantage or profit. Public office can also be abused for personal benefit even if no bribery occurs, patronage and nepotism, the theft of state assets, or the diversion of state resources, cited in (Agbu, 2003:3).

What we can deduce from the definitions above is that corruption entails any behaviour that deviates from accepted norm especially in the public space. Such behaviour usually confers undue and/or unmerited advantages on the perpetrator. Such behaviour also expresses the notion of a betrayal of trust especially in a democracy where public office is held in trust for the people. Corruption has various forms and dimensions. Aluko (2009:5) has identified nine forms namely: Political corruption (grand), Bureaucratic corruption (petty), Electoral corruption, Bribery, Fraud, Embezzlement, Favouritism, Nepotism. Other categorizations which do not differ from that of Aluko exist (Yaru, 2010; Adenugba, 2009; Omotola, 2006; Onigu, 2006; Aghemelo and Oarhe, 2003). What is important, however, is that in whatever form it manifests, corruption perverts public interest and unlawfully elevates private gain and advantage.

Corruption has taken a full endemic growth in Nigeria as a country. It gets more and more ingrained, especially as the economy deteriorates and the rate of crime increases. There is hardly any day a newspaper will not carry stories of corruption and/or financial crime. Corruption in Nigeria is not practiced systematically; it is systemic. Almost anywhere a service is to be provided within the Nigerian landscape, the service is not freely obtained. At the government sector, hardly anything, which has immediate touch on people goes on free of corruption: child education (admission, promotion), seeking employment, licensing or registration of small businesses, financial services, etc. In the private sector obtaining product distributorship, small or major contracts, provision of various needed services, etc. Common to both sectors are embezzlement, fraud and other financial crimes.

The report of a workshop for civil society organizations involved in the fight against corruption, organized by Zero corruption coalition, (ZCC) Lagos, December 11-12 2008, shows that the causes of corruption in Nigeria are: Weak Government institution, Poor pay incentives, Lack of openness and transparency in public service, Absence of key anti-corruption tools, Ineffective political processes, Culture and acceptance of corruption by the populace, Absence of effective political financing, Poverty, Ethnic and religious difference and Resource scramble.

\section{The Concept of Underdevelopment}

The concept of underdevelopment like development is shrouded in controversy, because it has no precise definition. However, some scholars see underdevelopment 
as the direct opposite or the other side of development. Others define it by comparing the levels of development of two or more societies, while others, see it as absence of development. In any case, underdevelopment is neither opposite nor absence of development. Underdevelopment according to Daniel (1980) refers to the state of an economy or an economy of a satellite economy characterized by low real income per capita in comparison with those of North America and West Europe. Such economy Daniel said characterized by illiteracy, poverty, over-population and diseases. Underdevelopment in this discourse can be defined as "a process in which a country has not sufficient developed." Underdevelopment scholars argued that this status of insufficient development and under employment of human and natural resources was acquired through historical circumstances such as slavery, colonialism and neocolonialism.

There is no gainsaying that the underdevelopment of any country poses devastating consequences on all ramifications of national development (social, economic, political and cultural). When a country is underdeveloped, it has far reaching effects on the entire populace as several elements within the country's landscape are either poorly unattended to or completely unattended to. Economic development for instance is viewed as a growth process that requires the systematic reallocation of factors of production from a low productivity, traditional technology, decreasing returns, mostly primary sector to a high productivity, modern, increasing returns, mostly industrial sector. But this is an antithesis in an underdeveloped society.

\section{Theoretical Frame of Analysis}

Social Scientists disagree even more intensely over the underlying causes of underdevelopment and the most desirable pathways to achieving development. As such, questions about the causes of underdevelopment and the pathway to development elicit very different responses from social scientists depending on the personal and cultural background and ideologies of the scholars. For instance, theories that blame third world backwardness on traditional cultural values generally have emanated from the West and the USA. On the other hand, theories such as Underdevelopment theory (UDT), Dependency or World System Theory which condemn western exploitation as the root cause of third world backwardness are particularly popular among the Latin American scholars and African analysts.

Furthermore, there seem to be an ineradicable tendency in Africa and even among third world countries that whenever we articulate reason(s) for our underdevelopment, we always heap the blame on our past colonial experience. As such we have mistaken historical explanation for historical justification for the persistent crisis of development in Nigeria. The UDT for instance posited that the 
underdevelopment of third world countries is as a result of their social and economic development being conditioned by external forces. Daniel (1980:50) posited that underdevelopment far from being an original or natural "condition" of the poor societies, is a condition imposed by the international expansion of capitalism and its inalienable partner, imperialism. Gauba, (2003) for instance added that dependency theory is an answer to the problems of neo-colonial exploitation of third world countries.

While most of the underdevelopment (UDT) scholars have concentrated on the past actions of the Europeans which have kept Africa and Nigeria underdeveloped, we need to move away from the past to the present. This is because UDT is to larger extent no longer serviceable in understanding contemporary Nigerian development predicament. It is tragic but nonetheless true that nearly five decades after independence, Nigeria's colonial economic structure has remained unchanged with its narrow production base and reliance on imported items. This paper therefore posits that even though it is hard to conceive how a country thoroughly pillaged, devastated, disoriented by the slave trade, colonialism and imperialism could be anything but underdeveloped; Nigeria's problem of development is to a larger extent caused by corrupt Nigerian leaders and private individuals. A critical look at post independent African states reveals that to be in power at the federal, state or local level is to be in charge of the treasury and use the wealth that belong to the people to illegitimately enrich themselves and party cohorts. As such this paper posits that the problem of development of contemporary Nigerian state can best be understood by borrowing from Richard Joseph Prebendal theory.

Richard Joseph conceive prebendalism as patron-client ties, which is the very channel through which one joins the dominant class and a practice which is seen as fundamental to the continued enjoyment of the perquisites of that class. Prebendalism is from the root 'prebend' which refers to as subsistence allowance granted to the state out of the estate of that state. This also includes revenue allocations of a state divided among each within its position. A prebend therefore becomes prebendal when such funds, revenue, grants meant for the development of the state are diverted for private or personal usage.

\section{The Social Cobweb Theory of Corruption}

While Richard Joseph's prebendal theory is an attempt at explaining how few people in positions of authority enrich themselves and create poverty of many. It has however not sufficiently accounted for why corruption has been sustained for many 
years. This gap is what the social cobweb theory of corruption has tried to fill in this paper. Theory is anchored on the Yoruba dictum which says that: the thief is the one who receive a stolen commodity and not the one who actually stole a commodity kept safe. From the foregoing, the explanation of substance of corruption can be found in the receivers of stolen good in Nigeria. The receivers are the eaters of corruption proceeds and they are found in all parts of Nigeria society and abroad. The eaters of these corruption proceeds eat in different styles and modes that paint the eating process in colours permissible and approved of by all.

This eating process is found in the traditional, religious, legal, educational, family institutions. The civil societies, unions and associations, professional bodies, media, ethnic nationalities, security agencies are not left out in the eating process. Indeed it has both local and international dimensions. All goes into the dining table and sometimes into the kitchen at the various levels each has the mastery of entering. And once each has eaten, each and all keep sealed lips on the burning issue of corruption because of the fear of oil stains that can be found on all eaters.

Giving credence to this assertion, political bureau (1988) observed that, while the struggle for and the acquisition of wealth impoverished governance and the culture of politics, the struggle for and the exercise of power created the context and culture of predation and ruination of the national economy. The April, 1997 Annual World Bank Conference cited in (Kenneth 2000:77) remains one of the most down to earth analysis of the link between corruption and development. The conference posited that corruption occurs everywhere throughout the world but it is of special concern in Africa where rampant corruption has expropriated the continent's enormous wealth, leaving little or nothing for its poorest citizens. Regrettably, it is those that impoverished the poor people in Nigeria that received traditional titles; religious recognitions; birthday wishes on pages of newspaper, radio and television; media award of excellence from the combination of corruption eaters highlighted above. Interestingly, no sooner had some of the corrupt public/private functionaries receive recognition than their corrupt practices made open. 
Nigeria's Table of Corruption and the Eaters of Corrupt Proceeds

\begin{tabular}{|c|c|c|}
\hline $\mathrm{S} / \mathrm{N}$ & The Eaters & Plate/mode of eating \\
\hline 1. & Traditional Institutions & $\begin{array}{l}\text { Traditional titles to federal/state/local government } \\
\text { official. } \\
\text { Courtesy visits at government houses }\end{array}$ \\
\hline 2. & Religious Institutions & $\begin{array}{l}\text { Prayer Mercantilism, Thanks Giving and Spiritual } \\
\text { Blessings }\end{array}$ \\
\hline 3. & Legal Institutions & $\begin{array}{l}\text { Judicial manipulations and outright Judgement } \\
\text { purchase }\end{array}$ \\
\hline 4. & Educational Institutions & Awards carefully wrapped in public lectures \\
\hline 5. & Family Institutions & Birthdays , Festivals and Ceremonies \\
\hline 6. & Civil societies & Public appearances, lectures and rallies \\
\hline 7. & Unions/associations & Courtesy visits, rallies, lectures \\
\hline 8. & Professional bodies & $\begin{array}{l}\text { Courtesy visits and subtle demand of the } \\
\text { impossible from their excellencies }\end{array}$ \\
\hline 9. & Media & $\begin{array}{l}\text { Business patronage e.g. advertisements, media } \\
\text { meetings with their excellences, media Awards of } \\
\text { 'excellence' }\end{array}$ \\
\hline 10. & Ethnic nationalities & $\begin{array}{l}\text { Threats and acts of public disturbances; amnesty } \\
\text { etc }\end{array}$ \\
\hline 11. & Security agencies & $\begin{array}{l}\text { Security meetings with their excellencies, } \\
\text { 'securing the communities, people, life and } \\
\text { property, }\end{array}$ \\
\hline 12. & Political institutions & $\begin{array}{l}\text { Inflated Contracts, political conflicts/ } \\
\text { gatherings/meetings. } \\
\begin{array}{l}\text { Courtesy calls and ceremonies of their } \\
\text { excellencies and notable politicians }\end{array}\end{array}$ \\
\hline 13. & International collaborators & $\begin{array}{l}\text { Buyers of stolen crude, artifacts and other items } \\
\text { from Nigeria }\end{array}$ \\
\hline
\end{tabular}

\section{Corruption Instances in Nigeria before and After Independence}

Corruption has become the second nature in most places in Nigeria. It is a major paralysis on the economy and the socio-cultural lives of Nigerians. As said earlier, the paper did not capture all the sectors or institutions that have been characterized by corruption in Nigeria, yet attention was focused on some key sectors or institutions. 


\section{Pre- Independence Corruption Instance}

In his book 'you must set forth at dawn', professor Wole Soyinka while at the university of London pre independence re-called a very humiliating instance of corruption amongst many other prior October first, 1960. He wrote:

I recall one publicly humiliating instance: a national figure, a truly revered name in a highly sensitive position. He got so carried away with his date that he paid for a one-night stand with a cheque, beneath which, just in case his scrawl was indecipherable, he had written his name, complete with official position. The girl, a brilliant student from an upper-class British family, but a notorious nymphomaniac, known to everyone, flounced to our table at the student's cafeteria, flaunted the cheque in our faces, asking in a loud voice what kind of a would-be independent nation would produce a political leader who could act so stupidly. I could so easily blackmail him with this, she boasted. We succeeded in coaxing the cheque out of her - a medical student promised to introduce her to a new 'virile' boyfriend if she surrendered the cheque. She agreed, and we destroyed it. She was completely indifferent to the money - it was sufficient that she had our 'national figure' in her power.

\section{Post-Independence Corruption Instances in the First Four Republics in Nigeria}

Corruption, though prevalent, was kept at manageable levels during the first republic. However, the cases of corruption during the period were sometimes clouded by political infighting. This is explained as follow:

Azikiwe was the first major political figure investigated for questionable practices. In 1944, a firm belonging to Azikiwe and family bought a bank in Lagos. The bank was procured to strengthen local control of the financial industry. Albeit, a report by the about transaction carried out by the bank showed though Azikiwe had resigned as chairman of the bank, the current chairman was an agent of his. The report wrote that most of the paid-up capital of the African Continental Bank was from the Eastern Regional Financial Corporation.

In Western Nigeria, politician Adegoke Adelabu was investigated following charges of political corruption leveled against him by the opposition. The report led to demand for his resignation as district council head. In 1962, Chief Obafemi Awolowo was indicated and the Coker commission of enquiry was set-up which found that a substantial amount of money was misappropriated from the coffers of the Western regional government. 
In the Northern region, against the backdrop of corruption allegations leveled against some native authority officials in Bornu. The Northern Government enacted the customary presents order to forestall any further breach of regulations. Later on, it was the British administration that was accused of corrupt practices in the results of elections which enthroned a Fulani political leadership in kano, reports later linking the British authorities to electoral irregularities were discovered.

Corruption for the most part of Gowon's administration was kept away from public view until 1975. However, some informed officials voiced concerns, Gowon critics labeled his governors as misguided individuals acting like lords overseeing their personal fiefdom. He was viewed as timid, in terms of being decisive against corrupt elements in his government. In 1975, a corruption scandal surrounding the importation of cement engulfed his administration. Many officials of the Defense and the Central Bank of Nigeria were involved in the scandal. Officials were later accused of falsifying ships manifest and inflating the amount of cement to be purchased. During the administration, two major individuals from the middle belt of the country were accused of corruption. The Nigeria government controlled newspapers: the Daily Times and the New Nigerian gave great publicity to denunciations of the administration of Gowon, and Federal Commissioner Joseph Tarka by the two critics, a situation which may signal a cause for exigent action on corruption. In 1975, the administration of Murtala Mohammed later went on and made reformist changes. After a coup putsch brought him into power, the government sacked a large number of government officials and civil servants, many of whom had been criticized for the misuse of power they wielded under the largely uneducated military of Gowon.

Corruption was deemed pervasive during the administration of Shagari. A few Federal buildings mysteriously went on fire after investigators started probe on the finances of the officials working in the buildings. Late 1985, investigations into the collapse of the defunct Johnson Mathey Bank of London shed some light on some of the abuses carried on during the second republic. The bank acted as a conduit to transfer hard currency for some party members in Nigeria. A few leading officials and politicians had amassed large amounts of money. They sought to transfer the money out of the country with the help of Asian importers by issuing import licenses. In 1981, a Rice shortage, led to accusations of corruption against the NPN government. The shortages and subsequent allegations were precipitated, by protectionism. After his election, the Nigerian government decided to protect the local rice farmer from imported commodities. A licensing system was created to limit the amount of rice import. However, accusations of favouritism and government supported speculation were leveled against many officials. 
In 1985, a cross section of political gladiators was convicted of different corrupt practices under the government of General Buhari. However, the administration itself was involved in a few instances of lapsed ethical judgement. It is on record that the General himself was on his way to removing a Nigerian Colonel from the army before his exit from power, though the removal may signal a hard-line on corruption, it is a far cry from the 10-22 years of imprisonment, politicians under Shagari were sentenced to.

The regime of General Babangida is seen as the body that legalized corruption in Nigeria. His administration refused to give account of the Gulf War Windfall, which is estimated to be $\$ 12.4$ billion. He annulled a democratic election in Nigeria on June 12, 1993 and decided to install Ernest Shonekan as his successor in August 27, 1993 when he stepped down as head of the military regime. However, within 3 months of the handover, General Sani Abacha seized control of the government, while Babangida was on a visit to Egypt. The death of the General Sani Abacha revealed the global nature of graft. French investigations of bribes paid to government officials to ease the award of a gas plant construction in Nigeria revealed the global level of official graft in the country. The investigations led to the freezing of accounts containing about $\$ 100$ million US dollars.

In 2000, two years after his death, a Swiss banking commission report indicted Swiss banks for failing to follow compliance process in allowing family and friends of Abacha access to accounts and deposition amounts totaling \$600 US dollars into the accounts. The same year, a total of more than $\$ 1$ billion US dollars were found in various accounts throughout Europe.

\section{The Legislature and Corruption}

Under section 88 granting the legislature power of oversight over the executive arm or its agencies, the constitution reads in subsection 2(b) that such powers are exercisable for the purpose of enabling the National Assembly to expose corruption, inefficiency or waste in the execution or administration of laws within its legislative competence and in the disbursement or administration of funds appropriated by it. A deeper reflection on this provision would reveal that the legislature is not only being empowered but has a challenging responsibility to uphold the highest standard of ethics, transparency and accountability, efficiency and essentially, leadership by example which would serve as a spring board for a corruption-free and democratic society. However, observable trends within the legislature have revealed the contrary. While it is true that the Nigerian legislature have been involved in rule making through passage of several bills including two major anti-corruption laws (Independent Corrupt Practices and Related Offences Commission, ICPC, Act 2001 
and Economic and Financial Crimes Commission, EFCC, Act 2002, amended 2004) as well as several oversight functions, its internal conduct and perennial allegations of corruption against its members is rather hapless. Perhaps, a highlight of some of these could help drive the point home.

In 1999, hardly had the National Assembly settled down for legislative business when the lower house was engulfed in allegation of certificate falsification by the then Speaker, Alhaji Salisu Buhari. The Speaker according to The News Magazine faked certificate of the University of Toronto, Canada which the Speaker claimed to have attended and that he was below the age of 30years which he claimed and which qualified him to sit in the lower house (The News, June 6, 1999). Indeed, the report shocked the whole nation including the Presidency thereby casting shadows of doubt over viability of the nascent democracy. After much controversy that involved denials and counter accusations between the speaker and the magazine, the speaker finally resigned his speaker-ship and vacated his seat in the house when the truth eventually became blown open. In addition, he was tried and convicted by the court for fraud and forgery and, sentenced to one-year imprisonment or a 'ridiculous' option of fine of 2000 Naira. Despite the fact that this judgment generated sharp reactions from the public, still, he was given state pardon by the President in 'the spirit of unity and national reconciliation' (The Punch, July 15, 1999: 1-2; July 22, 1999: 1-2; July 29, 1999: 1-2 and May 25, 2000:1-2; Ogundolapo 1999:30). The dust of the Buhari saga had hardly settled when allegations bothering on perjury were levied against the Senate President, Evan(s) Ewerem by the Tell magazine. Among others, he was accused of being an ex-convict having being jailed abroad for stealing; document and age falsification and indictment for financial impropriety when he was on the board of the Nigerian Airports Authority in the second republic as well as when he was governor of lmo State between 1992 and 1993. He was also accused of discrepancy in his name which reads Evan in some of his documents and Evans in some others (Tell, August 9, 1999; The Punch, August 3, 1999:1-2; The Punch, August 6, 1999: 1-2). He was eventually impeached on November 18 , after the senate was convinced of the allegations. Although Ewerem lost his position as senate president, he remained a member of the Senate House until the end of the first phase of the fourth republic in 2003. To say that all about allegations of corruption in the Nigerian Legislature was already heard is a mistaken conclusion. This is because, Chief Chuba Okadigbo who succeeded Ewerem as Senate President was himself removed, barely a year in office, for corrupt practices, among other misdeeds. He was accused of financial impropriety including spending a whopping 75 million Naira to buy Salah rams for some senators (The Punch, May 1, 2000: 1 and 6; May 10, 2000: 1-2; July 25, 2000: 1 and 4). Going by the number of senators (109), the above amount implied spending over five 
hundred thousand Naira $(\mathrm{N} 500,000)$ to purchase a single ram. Indeed, the level of corruption at the top echelon of the National Assembly is legendary.

In addition, there were other forms of allegations against the Senate in particular and the National Assembly as a whole. These included the controversial jumbo furniture allowance which legislators paid to themselves; allegations of contract inflation and awards without legal agreements and the National Assembly's unilateral inflation of its own budget in 2002 among others (see The Punch, August 9,2000: 1 and 4; July 26,2000: 1-2; July 29,2000:1-2, 16-17 and 25; July 27,2000:1-2; The News, August 21,2000). Expectedly, these allegations have not gone without sharp reactions from members of the public and the executive arm with the latter setting up probe panels in some instances. It was in this rowdy and cloudy atmosphere that the first legislative term of the fourth republic was concluded in May, 2003.

The beginning of another legislative term following the successful conduct of another general election in 2003 was thought by many to hold prospect for a robust legislative regime for two important reasons. First, during the elections, some members were reelected while some were voted out by their constituency including both leaders of the lower house and the senate. This coupled with election of some new legislators was expected to reinvigorate the house towards a purposeful deliberation. Second, while the first legislative term could be said to be immature, being the first after about sixteen years of non-existence as a result of military rule, the new legislature was expected to build on the experiences of its predecessor.

Thus, Nigerians were confounded when this era showed no significant departure from the past in terms of corrupt practices and perversion of integrity. Hardly had the legislators settled down for business when in August 2003, allegations of sharp corrupt practices reared their head. First was the allegation levied against the deputy Senate President, Ibrahim Mantu and another principal officer, Dr. Jonathan Zwingina by former Director General of the Bureau of Public Enterpnses, Nasir EIRufai that the two senators demanded 54 million Naira from him to facilitate his clearance in the senate as a ministerial nominee. Sensitive and stunning as this issue was, it was dismissed by other senators for what they considered as 'lack of evidence' (Weekly Trust, December 6, 2003; April 4, 2005:50). Then came the big bang. This was the allegation of bribery levied against the Senate President, Adolphus Wabara and other principal officers by the President in a nationwide broadcast. The president revealed that the Economic and Financial Crimes Commission (EFCC) uncovered an act by the then Minister for education, Professor Fabian Osuji who raised the sum of 55 million Naira which was used to bribe the Senate President and some other members of the senate and house of representatives in order to influence the education ministry's financial appropriation in the 2005 budget (Obasanjo, 2005). 
This no doubt stirred a controversy with the executive and the legislature raising accusation and counter-accusation while members of the public pitch tent with the former (The Punch, April 7, 2005: 1-2; The Guardian, April 8, 2005: 1-2). But despite denials by all the alleged (with the exception of Senator Adhigije who later became government's lead witness) and, the investigation panels set up by both houses of the National Assembly which were neither emphatic in admitting nor denying the allegations, all the actors including the Senate President and education minister were trialed for the offence. In the main, the Senate President bowed to public pressure by resigning his post while the president equally dismissed the education minister.

In 2004, a sitting senator, Uche Chukwumerije alleged that his colleague in the house, Senator Arthur Nzeribe, gathered some other colleagues at his official residence on 14 January with an offer of 5 million Naira for each to mobilize and support the declaration of an emergency rule in Plateau State. However, not convinced that the allegation is worth a hearing, other senators waved it off and asked Senator Chukwumerije to apologize to the house (The News, April 4.2005: 50). Also worth mentioning is the declaration by a member of the lower house, Honourable Haruna Yerima at a public gathering that some committees in the house go about collecting bribe from ministries and parastatals to induce members into taking favourable decisions. He alleged further that the Chairman, House committee on communications does facilitate distribution of MTN' recharge cards to honourable members. In his words:

whoever tells you there is no corruption in the house is in fact corrupt. Ministers and Heads of parastatals are often asked to bring money so that their budgets can be passed. MTN bribes us every month. It brings recharge cards worth 7,500 Naira monthly to each member (The News, April 4, 2005: 52).

Ironically, rather than investigate the substance of the allegation, he was suspended for a month for using what the house termed 'unparliamentary language' and bringing the house into disrepute.

\section{The Judiciary and Corruption}

The on-line reactions to Nigeria Bureau of Statistics' (NBS) findings constitute the real news. There were 17 comment-reactions to the NBS's findings. As many as many 16 reactions berated NBS's findings with respect to the finding that Judiciary was least corrupt in Nigeria. The commentators insisted that the courts are as corrupt as the police and the customs. Some of the comments are as hilarious as this; "No mind them. E be like say, you never try swear common affidavit?" First they are the most profitable when it comes to bribery maybe not in frequency. Also, less people have 
things to do with the judiciary compared with customs and police, so you have less number of people exposed to bribe request from them, but the few who do tell tales of serious corruption, bribery and grafts. To tackle corruption in Nigeria also rest solely on the judiciary at this point in time. The Legislative arm has put in place the enabling laws and ratification of the anti- corruption legislations. The Executive arm has ICPC and EFCC doing their jobs - albeit in a dysfunctional manner, but how many such corruption cases has the judiciary brought to an end. They allow it to go on forever, accept all manner of trials within trials, at tale end, it ends in plea bargain. Even when it is not, it is sadder for you to steal a goat and be arraigned in Nigerian court than to steal billions, for the latter will be asked to pay back a pittance while the former will be given lengthy jail terms with "hard labor to serve as deterrent to other would be goat stealers". How come we now have lots of Billionaire Judges?

In fairness to NBS, the Bureau acknowledges the limitations of its survey. It notes that not many of the business people turned to the justice system to resolve their disputes anyway. Only 20 percent did. Whatever the veracity of the findings, what should be a source of worry is that the judiciary is listed as corrupt at all, even if "least". The real food for thought lies in the reactions of the public which by all standard damn the judiciary as being as corrupt. One commentator, in an attempt to damn Nigeria's courts, ridiculed Nigeria's standard altogether. According to him Nigeria's judiciary might be "least corrupt in Nigeria i.e. by Nigerian standards but probably most corrupt in the world, by international standards" We must therefore not be alarmed that Nigeria's judiciary is perceived as part of the cancerous corruption that rot underdevelopment Nigeria.

\section{Corruption in the Business setting}

Several business surveys indicate that corruption is widespread and constitutes a major obstacle for companies operating in Nigeria. For instance, the companies surveyed in the World Economic Forum Global Competitiveness Report 2009-2010 consider corruption to be among the most problematic factors for doing business in Nigeria. Furthermore, the World Bank and IFC Enterprise Surveys 2007 report that $25 \%$ of companies surveyed in Nigeria consider corruption to be a major constraint, and $41 \%$ of companies report that they expect to pay facilitation payments to public officials to 'get things done'. Nigeria's public procurement system is also reportedly prone to corrupt practices, with as many as $45 \%$ of companies expecting to give gifts to public officials in order to secure a government contract. The state level of governance is reported to be more corrupt than the federal level and has direct control of many areas important to business activity. State agencies tend to impose a wide range of fees, licenses, fines and taxes arbitrary. Some companies even report that they avoid posting signs identifying their factories, claiming that to do so would be an 
invitation to corrupt officials to stop by and solicit bribes. Recently the National Bureau of Statistics (NBS) released its first ever crime and corruption survey in Abuja". The report's statistics deal with impact assessment of corruption on Nigerian businesses based on the experiences of many entrepreneurs. Of course there was a general consensus that corruption impedes businesses. According to the report, "71 percent of the over 2,200 businesses questioned said corruption was a major obstacle to their operations, second only to crime and political instability".

\section{Corruption in Nigeria Stock Exchange}

The Nigerian Stock Exchange (NSE) under the leadership of its former directorgeneral, Prof. Ndi Okereke-Onyuike, was characterized with huge corruption. A report revealed showed that the council of the NSE and employees allegedly shared a total of N3.362 billion as bonuses and productivity allowances in three years, in contravention of the provisions of Companies and Allied Matters Act (CAMA) and Memorandum and Articles of Association (MEMART) of the exchange. The document indicated that the money shared was in respect of 2006, 2007 and 2009 financial years. The Exchange was said to have disregarded provision of CAMA and MEMART, a development that made its external auditors, Akintola Williams Deloitte, who reviewed the 2009 accounts of the Exchange. The document obtained showed that N1.2 billion was distributed to employees and council members as bonuses and share of surplus respectively in 2009. Before then, N428 million and N1.74 billion had been shared among the employees and council members in 2006 and 2007 respectively. Faulting the sharing of these funds, Akintola Williams Deloitte said: "This is contrary to section 26(3) of CAMA, Cap C20 LFN 2004 and section 6 of the MEMART of the Exchange, which stipulated that the income and property of the Exchange shall be applied solely towards the promotion of the objects of the Exchange and no portion thereof shall be paid or transferred directly or indirectly by way of dividend, bonus or otherwise."

In 2008, the Exchange was reported to have spent N186 million to buy Rolex watches for long serving employees. Investigators' reports revealed that "at the beginning of 2008, the NSE expended the sum of N45 million in purchasing 64 Rolex watches for presentation to employees who had served the NSE for 10 years". The report also noted that "later in the same year, Candy Floss Limited was given N95 million for an additional purchase of 91 Rolex watches, and subsequently, after the award ceremony, another 10 Rolex watches at the cost of N46 million were purchased." Meanwhile, the investigators said they observed that the award ceremony document showed that only 73 out of the 165 Rolex watches purchased were actually presented to the awardees, meaning that, 92 Rolex watches valued at N99.5 million were unaccounted for. The investigators further observed that the schedule containing the 
list of staff members eligible for long service awards only contains 63 names; suggesting that 10 additional and unauthorized people received presentations. Furthermore, Candy Floss Limited, according to the report, was given N100 million to purchase 14 cars to be presented to employees who had served the NSE for 25 to 30 years. At the same time, the report said that, three cars purchased by the NSE in January and March 2008 for N59 million- one Land Cruiser purchased for N30 million, and two Lexus cars purchased for N29 million- were written off the NSE books at the end of the same year by their allocation to the long service Award account, as part of the gifts given during the ceremony. Meanwhile, the award ceremony document showed that only seven people were presented with cars, compared to the 14 cars which were to be purchased by Candy Floss Limited and the three additional cars written off; meaning that 10 cars, valued at approximately N66 million, were unaccounted for.

\section{Corrupt Practice by Nigeria Police}

It has been alleged that some unscrupulous officers rent firearms to criminals who use them to harass the public and engage in highway robberies. The police are also alleged to be collecting an unauthorized fee before granting bail to anyone who is arrested. Some police in traffic control collect a graduated illegal charge on all operators of inter- and intra-city transport. This is a norm we see on almost all the highways in Nigeria where several checkpoints are installed by the Nigerian police stopping cars and buses with reckless abandon all in a bid to collect unwarranted monies from transporters. There were even instances reportedly where these vehicle stoppages have led to fatal accidents on our highways leading to loss of lives and properties. Not until very recently was the act phased out by the Inspector-General of Police, Mohammed Dahiru Abubakar who said no police officer must be seen on Nigerian highways collecting illegal charges. Infact, in many social circles in Nigeria, the Nigerian Police Force is seen as an extremely corrupt establishment.

\section{Religion and Corruption}

Many churches and mosques have introduced the doctrine known as the "Prosperity Gospel" in Nigeria. According to Abogunrin (2007), the summary of "Prosperity Gospel" is as follows: If you come to Jesus or Allah, he will save you, give you all you want, including good health, make you rich and successful, and free you from poverty and disease. The chief product of what is offered is the "New You", instead of the "New life" in Jesus Christ or Allah. Since poverty is seen as evil in the churches and mosques in Nigeria, everybody is struggling to be free from it at all cost. Biblical and Koran passages are being interpreted to meet the needs and expectations of the followers. In this case, many people are drifting away from the 
mainstream African independent churches. The way many churches and mosques raised money for "God's work" in Nigeria is questionable. Abogunrin said "You can go to a church with a car and good shoes, but return home barefooted, and with nothing after donating all the money a person has on himself, he is encouraged to sow seed by parting with his car, shoes, bags, jewelries. There are cases or stories of people embezzling money from their offices and donating it to the churches in the name of prosperity.

Many Nigerians in search of quick miracles and in a bid to put an end to a life of misery and dejection quickly fall into these "kind of preaching" to do anything being proffered by these 'clerics' to free themselves of the poverty. Suffice here to say that many have fallen into these due to the economic conditions that Nigerians find themselves. Those in the churches and mosques who don't have wish to have and those who already have wish to have more. We therefore hear of religious leaders who have countless private jets, cars, and houses while members of their congregation live in abject poverty. It therefore means that these leaders live on the monies pooled in from their poor congregation by way of their 'sweet' preaching.

\section{The Family Institution and Corruption}

According to sociologists, the family institution is the primary agent of socialization in any society. Unfortunately, many households in Nigeria socialize their children on corruption and neglect societal norms and values. Highly upheld values of the family such as integrity and honesty, respect for the rules and regulations have all gone with the wind in the instance that it is even the parents that teach their children to be 'smart', to 'wake up' and not be left behind. Most parents enroll their children examinations like WAEC, NECO, NABTEB or JAMB in special centres in order for them to pass once and for all and enter higher institution quickly. They bribe internal and external examiners for their children to come out in flying colours in the exam. There are cases where parent give their children/wards money to settle their lecturers or teachers to pass. Some even call the lecturers or teachers themselves and directly settle them for their children/wards to pass. Some parents give bribe to the police etc in the presence of their children, which make their children think that bribe is a normal thing. After all, my father or mother does it-so they say. Nowadays in Nigeria, most parents even support their children who engage in internet fraud known as "yahoo yahoo" (internet fraud) in order to get rid of poverty in their family. Most parents tend to encourage their daughters to marry suitors who give them money and buy them things without bothering about how these suitors make money. 


\section{Consequences of Corruption and Path to Underdevelopment in Nigeria}

Suffice to say that the paper did not capture all the sectors or institutions that have been affected by corruption in Nigeria, yet attention was focused on some of them, which are key to the society. On the basis of fallen primary institutions that make up the society, corruption has encouraged underdevelopment in Nigeria in the following ways:

The family is the primary agent of socialization and where values, norms and culture of the society are preserved and transferred from one generation to another. However, most families in Nigeria has turned deaf ears to societal norms and values, and embraced corruption as a means to survival. Our society no longer pays much emphasis on hard work and patience as it used to be. Most parents no longer bother on how their children make money. Some parents even encourage their daughters/female wards to go into prostitution, their boys to engage in internet fraud and stealing because of money. This is largely due to high level of poverty and unequal income distribution, flamboyant demonstration of individual materialistic possession and exploitation of masses by the few powerful rich people in the society, and the inability of our leaders to give to the people of Nigeria what belong to them basic infrastructure, employment and safety of lives and property. The resultant effect of this to Nigeria is bad image among the international communities, and lack of trust and social conflicts. Where this is the case, as it is now, underdevelopment will be the order of the day.

Economically, Corruption lowers investment and retards economic growth. It holds back foreign investors in investing in a corruption prone society like Nigeria. Corruption by our leaders results in violation of the economic rights of the masses and vulnerable, denial of the benefits of free and open competition (Igbuzor, 2008) and infrastructure. Corruption leads to the depletion of national wealth. It is often responsible for increased costs of goods and services, the funneling of scarce public resources to uneconomic high profile projects at the expense of the much needed projects such as schools, hospitals and roads, or the supply of portable water, diversion and misallocation of resources, conversion of public wealth to private and personal property, inflation, imbalanced economic development, weakening work ethics and professionalism, hindrance of the development of fair in market structure and unhealthy competition. Large scale corruption hurts the economy and impoverishes entire population.

From the Social Perspective, According to the Lima Declaration, the impacts of corruption include: the erosion of the moral fabric of society, violation of the social rights of the poor and vulnerable. In the Social Sphere, corruption discourages people 


\section{Nigeria's Cobweb of Corruption and the Path to Underdevelopment}

to work together for common good. Frustration and general apathy among the public result in a weak civil society. Demanding and paying bribes becomes the tradition. It also results in social inequality and widened gap between the rich and poor, civil strife, increased poverty and lack of basic needs like food, water and drugs, jealousy, hatred and insecurity.

Politically, corruption in Nigeria undermines democracy, subversion of the rule of law and denial of society, particularly the poor of their fundamental rights. It leads to weak electoral commission, law enforcement mechanism, judiciary and one party dominated state. This will in turn lead to inflation of voters, rigging of elections and deprivation of winners from weaker political parties, weak state, poverty and wide income gap between the rich and the poor; bribing to win contract, influenced service delivery, contract cutbacks, inflation of government contracts and non-payment of taxes by highly placed businessmen; lack of national commitment, weak state and complex bureaucratic process; bribery of public officials and distortion of due process/normal procedure in the public sectors; bad policies, non-pursuance policy objectives, policy failures, employment of incompetent hands as public officials and poor service delivery; poor salary scale, greed and weak law enforcement mechanism and state of anomie.

Educationally, education which is the best legacy any government can give to her citizens has been abused by number of factors. Within the university system, some students resort to "sorting" (finding ways, especially with money, of purchasing of high and unmerited mark from a lecturer in order to enhance their grade in examination). Employers of labour these days do not place so much value on some of the degrees supposedly carried by today's graduates. They now make them go through extra drillings in the forms of aptitude tests, strict interviews to be sure of what these graduates truly possess. Due to the high level of corruption in the educational system, poor students who can't even spell their names are churned out from the primary school and into the secondary school still lagging incredibly behind and are forced into the universities through some corrupt manners and then find it difficult to cope with the rigours of education. In addition, the Nigerian government does not pay serious attention to Educational standards in Nigeria- in terms of funding. No reliable libraries, adequate lecturers/teachers, laboratory equipment etc. in our educational institutions. The cry for these by Academic Staff Union of Universities and Nigeria Union of Teachers in Nigeria is rarely heard, but the fear of Boko Haram is like a sound of trumpet to the government.

In the Religious sphere, people now have miss-feelings on whether God really exist or who are the true messengers/prophets of God on earth in Nigeria? People no longer have trust and hope in most preachers of God's words. Attitude towards going to 
church/mosque is now negative, as most people believe it's a business centre. This has made many youths to indulge in crime, since most of the preachers against crime are criminals themselves, hence, moral decadence, high level of criminality and underdevelopment in Nigeria.

\section{Conclusion/Recommendations}

Corruption is a universal menace (Otite, 1986, Lash, 2003). It does not seem to have respect for geographical boundaries, creed, religion, class, race or ethnicity. As seen above, corruption is multifaceted in Nigeria. It has, and it is hindering development process in our country. Corruption has a lot of negative impact on every sphere of societal development in Nigeria: social, economic and political (Igbuzor, 2008). In Nigeria, it is not only that officials are corrupt, but that corruption is official ( cited in Adesina, 2011:56) and institutional. Overcoming a challenge like corruption in Nigeria is definitely not child's play. This is much more so in a country like Nigeria where corruption seems to have become "normal". In Nigeria, it would seem that not being corrupt is the aberration while being corrupt is the norm. According to the Lima Declaration, the impacts of corruption include: the erosion of the moral fabric of society, violation of the social and economic rights of the poor and vulnerable, undermining of democracy, subversion of the rule of law, retardation of development and denial of society, particularly the poor, denial of the benefits of free and open competition (Igbuzor, 2008) and poor infrastructure. However, it is important to note that the scope and scale of corruption varies from one country to the other. Whatever the scale and scope of corruption, the important thing about it is that according to Obasanjo, corruption on any scale is bad (Obasanjo, 1994).

Because corruption in Nigeria is now national, and that the over centralization and the control of means of survival by the grandfather spider has weakened almost all major institutions in the Nigerian society; created a Master- Servant, Lordship and Serfs relationship, which if not re-structured will continue to sustain corruption in Nigeria and perpetuate further development of underdevelopment of the Nigeria Scale and Society, there is need for a national reorientation starting from the least person to the most. Establishment of effective watch-dogs in strategic places to nip in the bud the tendency to commit these crimes is an urgent necessity. Everything must be done through public enlightenment and mobilization to successfully fight corruption in Nigeria. Corruption is a killer, but it must be killed. It requires the collective efforts of everybody to make the process work.

Therefore, Nigerians should shun corruption in all its forms and see it as a major problem to development in Nigeria. The administrative apparatus of ICPC and EFCC should be strengthened so as to enable them combat corruption effectively. This 
should entail removing immunity clause from any government official, avoiding political, religious and ethnic interference from any quarters. There is the need to ensure that nobody is above the law and that the laws should run its full course and that jungle justice is abolished in the Nigerian judiciary system. Nigerians should adopt good governance as article of faith. Moreover, there is the need for the leadership of any government to enthrone and ensure the observance of the principle of checks and balances. They need to show Nigerians their resolve to bring these evil acts to justice and the willingness on their part to prosecute anybody caught irrespective of whose ox is gored. Checks and balances is a corollary to the theory of separation of powers because it emphasis one arm of government being a watch dog over the other arm, each having been assigned its specific function according to the principles of separation of power. If we think we are not hurting the system, or are probably taking what we feel we deserve from public coffers, we are destroying the legacies that generations after us should live on and are recording our names in the annals of history of those who failed their country. Indeed, the existence of institutional checks and balances moderates the use of power associated with leadership position. This is necessary because as Lord Acton notes, power corrupts and absolute power corrupts absolutely.

\section{References}

Abogunrin, S.A. (2007). Biblical Studies and Corruption in Africa. Ibadan: Alofe Publishers.

Adenuga, A. A. (2009). Corruption in Nigeria - An Overview. Journal of Social Policy and National Productivity. Vol 1.

Adesina, F. (2011). "Bankole and System Failure" in Daily Sun July 8, 56.

Agbu, O. (2003). Corruption and Human Trafficking: The Nigerian Case. West Africa Review 4(1)1-13.

Aghemelo, A.T. \& Oarhe, O. (2003). Elections in Nigeria since the end of Military Rule. Africana Vol.4, No.2, page 9-34.

Akanbi, M. (2004a), 'Corruption, Accountability and Good Governance' in Saliu, H.A (ed.), Nigeria under Democratic Rule, 1999-2003 Vol. 1. Ibadan, Nigeria: University Press PLC pp.

Akanbi, M. (2004b), ' Current Policy Initiative and Frameworks for Combating Corruption in Nigeria' The Nigerian Social Scientist. Vol. 7 No. 1, March. Pp 2-6 
Aluko, Y.A. (2009) "Corruption in Nigeria: Concepts and Dimension" In Enweremadu David U. and Okafor, Emeka E. (eds.) Anti-corruption reforms in Nigeria since 1999: Issues, Challenges and the Way Forward. IFRA Special Research Issue Volume 3, 1-8.

Azuka, N (2012): Legislative, Executive and Judicial Graphic Ilustration on Corruption. Compass Newspapers Friday, June 2012

Basil, D.(1992). The Blackman's burden Africa and the curse of the Nation -State New York ,NY : Times Book.

Benjamin, A.O (2003)Monitoring Corrupuration : Evidence from a Field ExpeWorkind Paper no 11753 (November), Nber, Cambridge, MA.

Chuma, N. (2003). Diaries of a Dead African Villager House, Nigeria.

Daniel, A.O., (1980) Imperialism and Dependency: Obstacle to African Development. Fourth Dimension Publishers, Enugu, Nigeria.

Dele, I. (2006). Corruption and Nigeria's Moral Landscape. The Nation, Nigeria.

Dike, V.E. (2003). Corruption in Nigeria: A New Paradigm for effective control. Africa Economic Analysis. http://www.Africaeconomicanalysis.org

Economic and Financial Crimes Commission (2004). High Profile Cases. EFCCHighprofile cases.

Egwaikhide, C.I. (2009). Corruption in Nigeria. The Bone of Economic Growth and Development. Nigerian Journal of Accounting and Finance, Vol.1, No 1.

Gauba, O.P (2003) An Introduction to Political Theory. Macmillan India.

Global Competitiveness Index reports, 2009-2010.

ICPC Act (2001).

IFC Enterprise Surveys (2007).

Igbuzor, O. (2008) Strategies for Winning the Anti-Corruption War in Nigeria Abuja: Action Aid.

Jega, A. (2005) Abuse of power is the Bane of Nigeria. Third Trust Annual Dialogue.

Kenneth, N. (2000) corruption, leadership and the dialectics of development in Africa. Associated Printing and Litho Co. Ltd Enugu Nigeria.

Lash, N. A. (2003) "Corruption and Economic Development" Mimeo Loyola University, Chicago. 
Nigeria Bureau of Statistics Reports.

Obasanjo, O. (1994 ). "Key note address" in Mahudi, Abdullahi, Kwanashi, George Amale and Yakubu, Alhaji Mahmud (edds ) Nigeria: The State of the Nation and the way forward . Kaduna: Arewa House 18- 38.

Obasanjo, Olusegun (2005), Text of National Broadcast to the Nation. The News, Lagos. April 4, 2005 pp. 48-49 and Thisday, Lagos Thursday, March, 3, 2005.

Ogbeifun, L.B. (2007). Effects of petroleum Products Pipelines Vandalism on Society, Employee and Organisational Productivity: The Dilemma of Downstream Operation in Nigeria. www.louisbrownogbeifun.com

Ogundiya, L.S. (2009). Political Corruption in Nigeria: Theoretical Perspectives and some Explanations in Anthropologist 11(4), 281-292.

Ogundolapo, O. (1999), 'Buhari: The Jury is still Out' The Punch, Lagos August 11.

Olusegun, O. (1990). Inaugural Address, "was a new dawn delivered on May 9".

Omotola, J. S. (2006) "Through a Dark Glass Darkly: assessing the New War Against Corruption in Nigeria" in Africa Insight 36(3 and 4) 214-228.

Onigu, C.S. (2006) Anti-Corruption Campaign in Nigeria: A paradox. Makurdi: Aboki Publishers.

Oyinola, O.A. (2013). Corruption Eradication in Nigeria: An Appraisal. Free Web Tracker and Counter.

Political Bureau Reports (1988), Nigeria.

Report Transparency International, (T.I.) (2014), Germany. Accessed from www.gawrji.com/article5000/news5530.html

Ribadu, N. (2005). "Corruption: The Trouble with Nigeria. Available at http://www.gawrji.com/article5000/news5530.html

Tam, D.W. (2003). "How Africans underdeveloped Africa: Daily Sun, Friday, October 24, (News Paper).

Tanzi, V. (1995). The Economic of organized Crime. Cambridge: Cambridge University Press.

Transparency International (2002-2009). World Corruption Perception Index Reports and Ranking of Countries. 
Wole, S. (2006). "You must set forth at Dawn". Random House Paperback.

World Economic Forum, (2003-2010): Global Competitiveness Reports.

Yaru, M.A.(2010) "Economic perspective of Corruption in Public Sector. A theoretical explanation and lessons for Nigeria" in Ilorin Journal of Business and Social Sciences (IJBSS) 13(2) 143-153. Otite, O. (1986) "On the Sociological Study of Corruption" In Femi Odekunle (ed). Corruption in Development, Ibadan University Press.

\section{Newspapers Sources}

Tell, August 9, 1999, The Guardian, April 8, 2005, The News, April 4, 2005, The News, June 6, 1999, The News, August 21, 2000, The Punch, April 7, 2005, The Punch, August 3,6, 1999, The punch, August 9, 2009, 2., The Punch, July 15,22,29, 1999, The Punch, July 25, 26, 27, 29, 2000, The Punch, May 1, 10, 25, 2000, Weekly Trust, April 4, 2005, Weekly Trust, Dec. 6, 2003, Lagos, Nigeria.

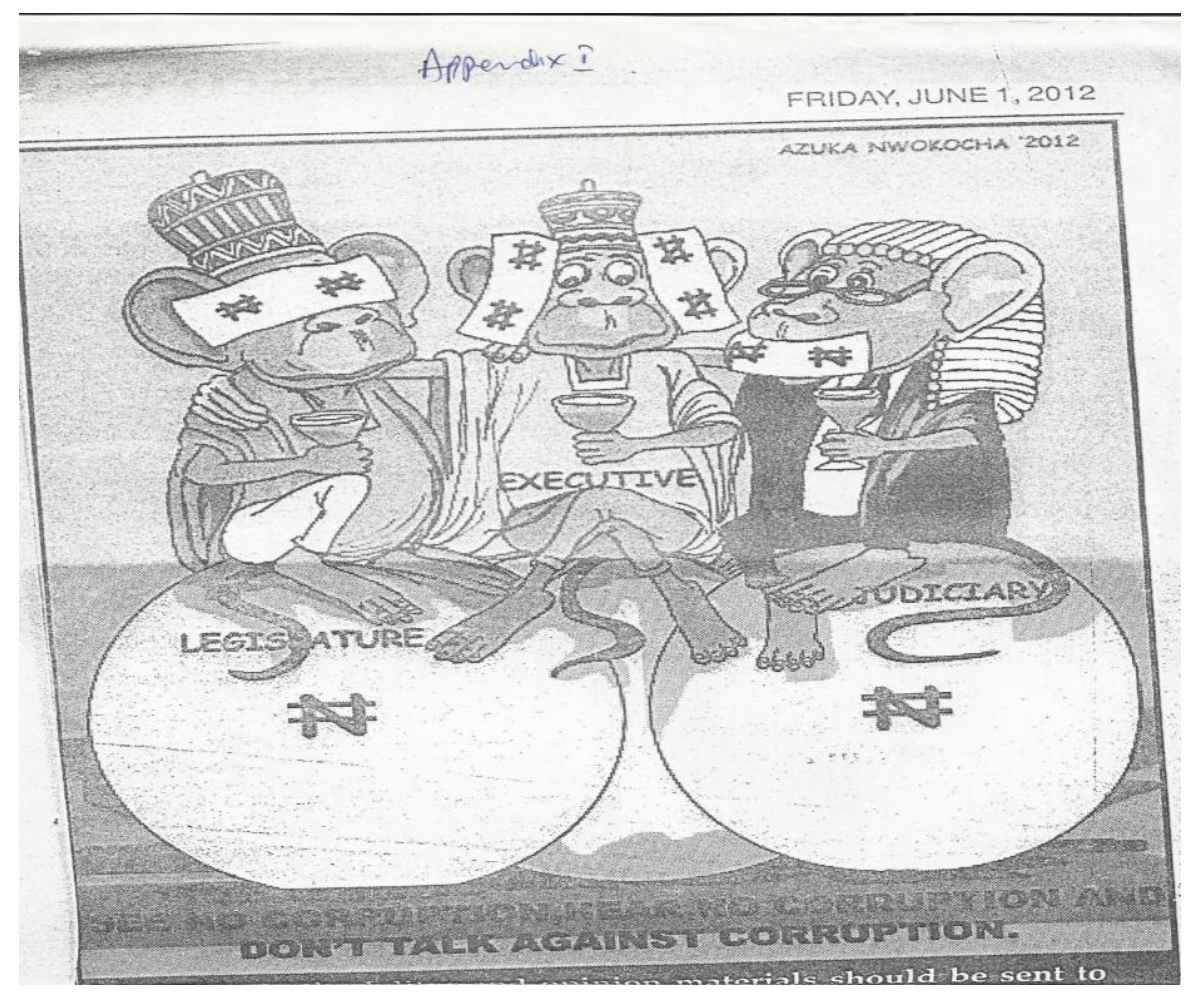

Copyright $\odot$ IAARR 2014: www.afrrevjo.net/ijah 